\title{
Latest Insights on the Diagnostic Approaches and Treatment Strategies of COVID-19
}

\author{
Sarah S. Hassanein ${ }^{a, b}$ Muhammed R. Sharaby ${ }^{a, c} \quad$ Noran M. Tawfik $^{a, d}$ \\ Suzan A. Rashed ${ }^{a, c}$ Mohamed Adel $^{a, e}$ Ayat Fayez $^{a}$ Heba Mansour $^{a, f}$ \\ Haitham M. Amerg \\ aBasic and Applied Sciences (BAS) Institute, Biotechnology Program, Egypt-Japan University of Science and \\ Technology (E-JUST), Alexandria, Egypt; 'boology Department, Faculty of Science, Cairo University, Giza, Egypt; \\ 'Botany and Microbiology Department, Faculty of Science, Alexandria University, Alexandria, Egypt; 'Zoology \\ Department, Faculty of Science, Suez Canal University, Ismailia, Egypt; 'Botany and Microbiology Department,

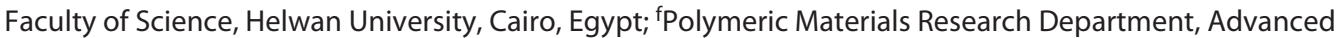 \\ Technology and New Materials Research Institute, City of Scientific Research and Technological Applications, \\ Alexandria, Egypt; 9Virology Department, Faculty of Medicine Veterinary, Cairo University, Giza, Egypt
}

\section{Keywords}

Coronavirus disease-19 - Life cycle · Molecular diagnosis · SARS-CoV-2 - Therapeutics

\begin{abstract}
Background: COVID-19 has emerged as the most serious pandemic in the 21 st century to date. COVID-19 patients may develop various disease symptoms that hinder the accurate clinical diagnosis. Summary: Routine diagnosis of COVID-19 requires complementary investigations, including computed tomography, immunological assays, and molecular assays like real-time RT-PCR, loop-mediated isothermal amplification, metagenomic next-generation sequencing, and clusters of regularly interspaced short palindromic repeats-based assays. Clinically approved antiviral drugs available for the COVID-19 treatment are very limited. The most common measurements that enhance health condition and patients' viability are conservation fluid management, oxygen therapy, and antibiotics. Several therapeutic options have been developed or repurposed to prevent virus replication and/or modulate the immune response against virus in-
\end{abstract}

Karger@karger.com www.karger.com/int

Karger!

GOPEN ACCESS
(C) 2022 The Author(s)

Published by S. Karger AG, Basel

This is an Open Access article licensed under the Creative Commons Attribution-NonCommercial-4.0 International License (CC BY-NC) (http://www.karger.com/Services/OpenAccessLicense), applicable to the online version of the article only. Usage and distribution for commercial purposes requires written permission. fection. These options include various drugs that affect virus entry and membrane fusion, inhibit polymerase and protease activity, suppress the host pro-inflammatory cytokines, and utilize cell therapy approaches. Key Messages: In this review, we aimed to provide an up-to-date discussion on the current diagnostic options and therapeutic strategies used to control and manage COVID-19 in clinical and point-ofcare settings.

(c) 2022 The Author(s). Published by S. Karger AG, Basel

\section{Introduction}

COVID-19 has developed as the most serious pandemic in the 21st century to date. The causative agent SARS$\mathrm{CoV}-2$ is classified as a member of genus Betacoronavirus, subfamily Coronavirinae, family Coronaviridae, and order Nidovirales [1]. A characteristic feature of SARS-CoV-2 is its transmission via close contact with infected persons by exposure to sneezing, coughing, respiratory droplets, and aerosols (airborne transmission) [2-4]. Routine diagnosis of COVID-19 is based on the epidemiological history, clin- 
ical manifestations, and some complementary investigations, including molecular detection of viral RNA, bedside/ point-of-care (POC) testing, computed tomography (CT), and immunological assays like ELISA. Neverthelesss, SARS-CoV-2-infected patients may show a wide range of clinical symptoms such as dry cough, fever, loss of taste and/or smell, fatigue, headache, sore throat, myalgia, pneumonia, renal failure, diarrhea, septic shock, and others [5]. Therefore, complementary investigations are crucial for a better diagnosis of COVID-19 in clinical and POC settings [6]. Specimens for identifying SARS-CoV-2 infection may include nasopharyngeal swab/wash/aspirate, oropharyngeal swab, lower respiratory tract aspirate/lavage, sputum, whole blood, plasma, serum, urine, and stool [7, 8] (online suppl. Video; for all online suppl. material, see www.karger. com/doi/10.1159/000522336).

Unfortunately, the available and clinically approved antiviral drugs to prevent and/or treat COVID-19 are very limited $[6,9]$. The alternative adjuvant treatments, including conservation fluid management, oxygen therapy, and antibiotic use against secondary bacterial infections, are the only measures to support the health condition and enhance the patient's viability [10]. Based on the genomic organization of SARS-CoV-2 [1] and the molecular mechanisms of infection [11], several prospective therapeutic targets are available for the development of efficient interventions against SARS-CoV-2 [6]. In the following sections, the different methods used for diagnosing COVID-19 and the approaches used for developing specific antiviral chemotherapy will be discussed according to the most recent available data.

\section{Basic Structural and Functional Features of SARS- CoV-2}

SARS-CoV-2, like most coronaviruses, is spherical or pleomorphic in shape with an average diameter of 65-125 $\mathrm{nm}$ [12]. The viral genome is typically composed of single-stranded positive-sense RNA that extends from 29.8 to $29.9 \mathrm{~kb}$ in length [1]. Viral RNA is wrapped with the nucleoprotein subunits to form a helical nucleocapsid structure. An outer envelope is formed by the budding of the viral nucleocapsid from the endoplasmic reticulumGolgi intermediate compartment. Coronaviruses have a crown-shaped appearance as they possess club-shaped projections (spikes) of 20-nm length protruding from the viral envelope [13].

The genome of SARS-CoV-2 encodes for 4 structural proteins, including spike $(S)$, membrane $(M)$, envelope
(E), and nucleoprotein $(\mathrm{N})$, besides 23 nonstructural and accessory proteins [14]. RNA-dependent RNA polymerase (RdRp), in combination with other nonstructural proteins like nsp2 (RNA helicase) and nsp4, forms the polymerase complex that is crucial for RNA processing and virus replication [15]. RdRp plays a vital role in virus evolution since it controls the virus replication fidelity and consequently, the mutation rate and adaptation to sudden changes of host populations and new environmental conditions [16]. Other accessory proteins, rare in RNA viruses, were also described to gather at the cell membrane during virus budding from the host cell. These proteins include $2^{\prime}$-O-ribose methyltransferase, putative sequence-specific endo-RNAse, $3^{\prime}-5^{\prime}$ exonuclease, and ADP ribose 10-phosphatase [17].

$S$ protein is a type I membrane glycoprotein mediating virus binding to host cell and membrane fusion and is crucial for determining host susceptibility and transmissibility [18]. Two subunits have been described for $S$ protein, including $\mathrm{S} 1$, which has four core domains $\mathrm{S} 1_{\mathrm{A}-\mathrm{D}}$ responsible for cell attachment and $\mathrm{S} 2$, which is implicated in membrane fusion and virus entry into the host cell [19]. M glycoprotein has a long C-terminus cytoplasmic domain, a short $\mathrm{N}$-terminus domain protruding externally, and 3 transmembrane domains spanning the viral envelope [20]. This protein represents a chief organizer of virus assembly and budding by interaction with other structural proteins [21]. The $\mathrm{E}$ protein is the minor membrane protein engaged in different virus replication stages, particularly during assembly and envelope formation [22]. N protein is distinct from the other structural proteins of SARS-CoV-2 binding to the viral RNA forming the nucleocapsid [23]. The protein also augments RNA synthesis and folding and influences cell cycle and protein translation in the host cell $[24,25] . \mathrm{M}, \mathrm{E}$, and $\mathrm{N}$ proteins interact to stabilize the RNA-nucleoprotein complex within the internal core of virions, triggering virus assembly and budding [26].

\section{Current Diagnostic Measures for COVID-19}

Besides CT, which is critical for the initial diagnosis of COVID-19, the currently available diagnostic tests are divided into two major classes. The first class includes the molecular assays used for the identification of SARSCoV-2 RNA in clinical specimens, such as real-time RTPCR (rRT-PCR), next-generation sequencing (NGS), clusters of regularly interspaced short palindromic re- 
Table 1. Contemporary diagnostic tools for SARS-CoV-2: advantages and disadvantages

\begin{tabular}{|c|c|c|c|}
\hline $\begin{array}{l}\text { Diagnostic } \\
\text { tool }\end{array}$ & Common sample types & Advantages & Disadvantages \\
\hline rRT-PCR & $\begin{array}{l}\text { Sputum } \\
\text { Bronchial aspirates } \\
\text { Pharyngeal, nasal, and anal swabs } \\
\text { Bronchoalveolar lavage fluid } \\
\text { Blood } \\
\text { Feces [8-9] }\end{array}$ & $\begin{array}{l}\text { Sensitive and specific [29-43] } \\
\text { Rapid: } 1.5 \mathrm{~h} / \text { run } \\
\text { Closed system reaction (limited false-positive } \\
\text { results) [30] } \\
\text { Targets most viral protein genes } \\
\text { Structural (S, E, M, N) } \\
\text { Nonstructural (RdRp, ORF1a/b) [31-34] }\end{array}$ & $\begin{array}{l}\text { Requires well-equipped labs } \\
\text { Infrastructure is lacking in developing } \\
\text { countries [33] } \\
\text { Requires a satisfactory threshold of } \\
\text { virus concentration in the specimen } \\
\text { Delay of } 5 \text { days for switching from } \\
\text { premier negative to positive results [93] } \\
\text { False-negative results due to improper } \\
\text { handling [94] } \\
\text { Expensive [94] }\end{array}$ \\
\hline RT-LAMP & $\begin{array}{l}\text { Swabs (nasopharyngeal, oropharyngeal, } \\
\text { anterior nares, MTN } \\
\text { Nasal and bronchial aspirates } \\
\text { Bronchoalveolar lavage fluid }\end{array}$ & $\begin{array}{l}\text { Sensitive and specific [95] } \\
\text { Rapid (less than an hour) } \\
\text { Simple one-step amplification technique } \\
\text { Performed at constant temperature }\left(60-65^{\circ} \mathrm{C}\right) \\
\text { No need for sophisticated equipment } \\
\text { Low-cost reagents (stable at room temp) } \\
\text { Simple detection of positive results (color, } \\
\text { turbidity, and fluorescence) }\end{array}$ & Four to six primers \\
\hline CRISPR & Respiratory samples & $\begin{array}{l}\text { Sensitive and specific (100\%) [43] } \\
\text { Short turnaround time ( } 40 \mathrm{~min}) \\
\text { No false-positive results }\end{array}$ & Off-target results [94] \\
\hline mNGS & Respiratory samples & $\begin{array}{l}\text { High throughput [96] } \\
\text { Unbiased nature }\end{array}$ & $\begin{array}{l}\text { Long turnaround time (about } 20 \text { h) [43] } \\
\text { Relatively short reads [96] }\end{array}$ \\
\hline SHERLOCK & $\begin{array}{l}\text { Respiratory sample } \\
\text { Serum } \\
\text { Urine } \\
\text { Saliva } \\
\text { Blood }\end{array}$ & $\begin{array}{l}\text { A simple and rapid technique } \\
\text { Single sample handling step } \\
\text { Performed at a single temperature } \\
\text { Visual result interpretation } \\
\text { No need for sample extraction } \\
\text { Suitable for home testing [46] }\end{array}$ & $\begin{array}{l}\text { Technically demanding } \\
\text { RNA/DNA oligonucleotides and } \\
\text { reaction mixtures are not commercially } \\
\text { available } \\
\text { Multistep nucleic acid amplification } \\
\text { Less useful in gene expression profiling } \\
\text { [97] }\end{array}$ \\
\hline Chest CT & Chest & $\begin{array}{l}\text { Noninvasive [33-99] } \\
\text { Screens even asymptomatic people } \\
\text { Sensitivity (86-98\%) [93] }\end{array}$ & $\begin{array}{l}\text { Expensive } \\
\text { Requires technical expertise [33] } \\
\text { Results may confuse with other } \\
\text { infections }\end{array}$ \\
\hline
\end{tabular}

MTN, mid-turbinate nasal.

peats (CRISPR), reverse transcription loop-mediated isothermal amplification (RT-LAMP), specific high-sensitivity enzymatic reporter unlocking (SHERLOCK), and nucleic acid sequence-based amplification (Table 1) [27]. However, the second class comprises the immunological assays used for detecting virus-specific antibodies in patients' sera [28].

Latest Insights for COVID-19 Diagnosis and Treatment

\section{rRT-PCR Assays}

rRT-PCR is the gold standard for detecting a wide range of pathogens, including SARS-COV-2, because of its sensitivity, specificity, and rapidity [28]. Scientists have used several targets like RdRp, ORFla/b, E, N, and $S$ genes to detect SARS-CoV-2 by rRT-PCR. Testing two molecular targets in parallel are mostly recommended to avoid cross-reactivity with other human coronaviruses 
and reduce the potential of false-negative results caused by the generation of new virus variants over time [29]. Studies have utilized conserved sequences from $\mathrm{S}$ and RdRp [29], E and RdRp genes [30], and ORF1b and N genes for the development of reliable rRT-PCR assays. It was suggested that the ideal design for a SARS-CoV-2 rRT-PCR assay is to target at least one conserved region and one specific region [29]. The WHO recommends using a gene-based assay for initial screening and RdRp gene-based assay for result confirmation $[29,30]$, whereas the CDC identified two loci in the $\mathrm{N}$ gene for getting the best results [31].

Genome analysis of a wide array of SARS-CoV-2 strains has identified three genes: RdRp, E, and N, as highly conserved. The developed assays that target these genes have shown variable analytical sensitivities, where E- and RdRp-based assays were highly sensitive (detection limit of 3.9 and 3.6 copies per reaction, respectively), and $\mathrm{N}$ based assays were the least sensitive ( 8.3 copies per reaction) [30, 32]. Similarly, a Chinese group has compared the results of three assays targeting RdRp, S, and N ORFs using 273 clinical samples from confirmed cases and confirmed that RdRp is the most sensitive and specific for the use in laboratory diagnosis of COVID-19 [33].

A notable drawback of rRT-PCR is that it could not determine the infection early enough to apply the control measures, particularly in asymptomatic patients [32]. The sensitivity of the assay also depends on the type of sample used for testing. In a cross-sectional study that involved 1,070 specimens collected from 205 confirmed cases, the highest sensitivity was obtained with bronchoalveolar lavage (93\%), followed by sputum $(72 \%)$, nasal swabs (63\%), and pharyngeal swab (32\%) [32]. The viral RNA was also detected in the feces but not in the urine of infected patients. Evidence also suggested using the saliva as an alternative sample with less need for protection facilities; however, it still needs validation.

A combined Influenza SARS-CoV-2 Multiplex rRTPCR Assay (Flu SC2) was launched by the CDC in July 2020 to detect SARS-CoV-2, influenza A, and influenza B viruses simultaneously in upper or lower respiratory specimens. The assay is extremely sensitive and can be used as a powerful tool to evaluate specimens from patients in the acute phase of infection [34]. The Flu SC2 Multiplex Assay allows public health laboratories to run three tests in a single reaction tube with fewer test reagents and higher throughput. Flu SC2 is currently under improvement, utilizing sequence data that were not available during the first release of the assay [34].

\section{Reverse Transcription Loop-Mediated Isothermal} Amplification

RT-LAMP is a one-step RNA amplification technique used for the diagnosis of many infectious diseases. The advantages of RT-LAMP over RT-PCR are shown in Figure 1 . The assay is performed at a constant temperature between 60 and $65^{\circ} \mathrm{C}$, and the amplified target is identified using simple methods like visual inspection of color change or turbidity, measurement of fluorescence, and agarose gel electrophoresis [35]. Recently, several research groups have developed optimized RT-LAMP systems as rapid and straightforward choices for COVID-19 diagnosis in regions lacking the facilities and equipment [36-41]. The developed assays use primer sets that target conserved sequences in different genomic regions of SARS-CoV-2 (either separately or combined), including ORF1ab, $\mathrm{S}$, and $\mathrm{N}$ genes. In particular, the primers are designed to target the RdRp region of ORFlab and have shown higher amplification efficiency and specificity [39].

The RT-LAMP assays could amplify the specific sequences in a single-step process without the need for RNA extraction. Also, obtained results are quick with high specificity, sensitivity, and minimum cross-reactivity [40]. It was reported that the colorimetric LAMP is a quantitative method [41]. In two different studies, there was a high degree of compatibility between the results of RT-LAMP and the gold standard rRT-PCR $(89.9 \%$ and 100\%) $[36,38]$. The technique was also adapted for use with the commercial Eppendorf PCR tubes combined with the 3D-printed incubation chamber [41].

\section{Metagenomic NGS and CRISPR}

Metagenomic NGS, high-throughput sequencing, is now playing a pivotal role in diagnosing unexplained pathological conditions, particularly those caused by atypical causative agents. This method has many applications including genome sequencing ( $>1$ million base pairs per single run), diagnosis of cancer, inheritable disorders, and infectious diseases, besides large-scale recognition of novel viruses and virus strains. In conjunction with the bioinformatic tools, the metagenomic NGS has greatly inspired the contemporary viral pathogenesis and diagnostics, especially during the current pandemic [42]. NGS has recently been utilized in routine screening of viral genomes for genetic drifts due to its high sensitivity [43]. At the start of COVID-19 outbreak,

Fig. 1. Advantages of using RT-LAMP over RT-PCR as a diagnostic method for SARS-CoV-2 detection.

(For figure see next page.) 


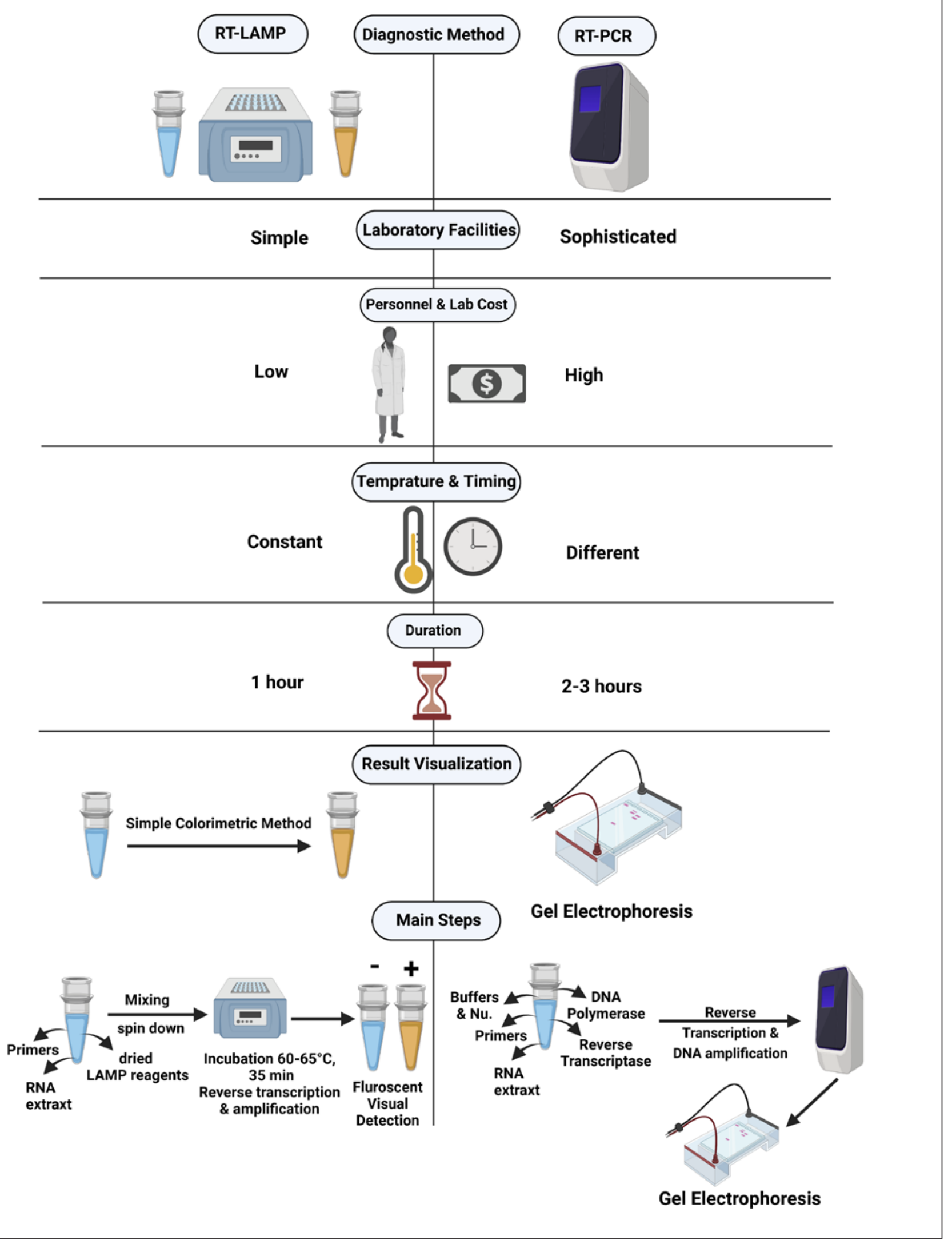


the patients' samples of acute respiratory distress syndrome (ARDS) indicated negative for all suspected pathogens. NGS was the only tool that enabled scientists to identify the etiological pathogen as novel coronavirus [44]. Yet, the costs of NGS chemicals and equipment limit its use as a laboratorystandard diagnostic technique [42].

CRISPR/Cas is a powerful gene-editing tool and a promising treatment for many diseases. Different kinds of Cas proteins were demonstrated, among which Cas12a and Cas13a are efficient in diagnostic purposes, and Cas9 is specialized in gene editing [45]. A CRISPR/Cas12based assay was developed to detect SARS-CoV-2 in clinical samples and was termed SARS-CoV-2 DNA Endonuclease-Targeted CRISPR Trans Reporter. Another isothermal CRISPR/Cas13-based assay (CRISPR-nCoV) was developed and compared to rRT-PCR and NGS [43]. CRISPR-nCoV had a sensitivity and specificity of $100 \%$ compared to the reference assays. The assay seems a promising diagnostic tool that offers a shorter turnaround time, even in under-resourced settings with no need to use thermal cyclers [43].

SHERLOCK is an innovative technique that involves amplifying specific viral RNA sequences, followed by detecting the amplicons using CRISPR-mediated collateral reporter unlocking $[32,46]$. An RNA guide sequence, together with Cas13a, binds specifically to the amplified fragments forming a complex [47]. This binding stimulates activation of Cas13a to cleave adjacent fluorophorequencher probes emitting fluorescence. SHERLOCK was used to distinguish Zika virus from dengue virus in the serum and urine in concentrations lower than 2,000 copies/mL. It could also detect several bacterial strains and identify mutations in cell-free tumor DNA [48].

SHERLOCK Testing in One Pot is a modified method based on SHERLOCK's use in a simple platform. The technique does not require RNA extraction and is performed in a single step using a single reaction temperature. STOPCovid was recently developed for use in POC settings and household facilities to face the growing need for COVID-19 diagnostics [46]. The developed assay utilizes lysis buffer (QuickExtract) to release SARS-CoV-2 RNA, which is detected after amplification, RNA binding, and Cas13a activation on a commercially available paper dipstick by the naked eye [46].

\section{Immunological Testing}

Immunological testing, particularly serological assays, is relatively inexpensive, easier to perform, and requires fewer tools and less technical proficiency than nucleic acid-based assays. However, a recognizable level of antibod- ies cannot be detected before elapse of several days to weeks of infection. Therefore, serological tests are not recommended to diagnose acute SARS-CoV-2 infections except in very rare conditions [49]. They may be used for confirming or excluding the infection in late stages [50].

Serological tests are mainly used to determine former infection with SARS-CoV-2 and help diagnose clinically suspicious patients with negative PCR results. Patients are considered positive when they have recognizable IgM antibodies or an increased IgG titer $(4 \times$ or more) in the convalescence sera compared to the acute phase sera [51]. The antibody dynamics of SARS-CoV-2 are very similar to most acute viral infections, where the IgG level increases as the IgM level decreases [31]. In general, IgM starts to appear in the patient's serum by the 5 th day postinfection, whereas IgG does not develop before the 14th day [51]. Likely, several serological tests have been authorized for use, under the emergency, by the US FDA for SARSCoV-2 diagnosis. The majority of currently authorized serological tests detect IgM and IgG in infected persons' blood by ELISA, lateral flow cassettes, or chemiluminescence platforms [52].

Other assays that determine cellular markers and immune cells' levels are also described as practical approaches for COVID-19 diagnosis. Patients mostly show higher D-dimer and C-reactive protein levels and low levels of leukocytes, lymphocytes, and blood platelets [53]. There is much to be determined about the value of these parameters and serological testing in monitoring and diagnosing COVID-19.

\section{Computed Tomography}

Despite the availability of many sensitive and specific diagnostic assays for SARS-CoV-2, chest CT is still significant as an initial screening tool [53-57]. A chest CT scan is a cross-sectional image taken across a patient's chest at different angles. Several scientists claimed that chest CT is more credible than rRT-PCR in COVID-19 diagnosis since rRT-PCR may render false-positive and/ or false-negative results [58]. Others confirmed that even asymptomatic patients could be screened by chest CT [54]. It was concluded that patients with intermediate symptoms who display inconspicuous chest X-ray findings are positive COVID-19 even if their rRT-PCR results are negative [55]. Recently, the Fleischner Society declared three main scenarios for using imaging as a primary diagnostic tool, including (a) cases with mild respiratory features yet have risk factors for disease progression, (b) cases presenting with moderate to severe features of COVID-19, and (c) cases with moderate to severe 
symptoms with limited testing resources and within a high frequency of disease [59].

Chest CT mostly shows peripheral, bilateral, and ground-glass opacity in COVID-19 patients [54]. However, the imaging pattern varies according to the disease stage and severity [60]. Chest CT exhibits interstitial changes and multiple small plaques in the early stages, besides common patterns like lymphadenopathy, cystic changes, pleural effusion, bronchiectasis, and nodules [54]. In more advanced stages, an infiltrating opacity is recognized with lung consolidation (solid or fluid material in compressible lung tissue), multiple bilateral ground-glass opacity, and fibrous stripes or interstitial thickening $[54,61]$.

\section{Breathe Print}

The COVID-19 breath test has developed to exploit the advances in sensor technologies for breath diagnostics based on the crystallo-chemical principle of selective gas detection [62-64]. An electronic signature can be generated based on the presence and concentration of a specific chemical compound (biomarker) in a single exhaled breath, as opposed to other nose technologies that use nonselective sensors and sample the entire breath for patterns drawn by machine learning algorithms [65]. Exline et al. provided the first study to use a nanosensor breathalyzer to detect viral infection from exhaled "breathe prints" in critically ill patients. The test is noninvasive and quick. Due to epidemiological concerns and regulations regarding research staff exposure, the analysis was not done at the bedside, but it could be done easily in clinical practice [66]. This COVID-19 sensor captures the interaction and relative ratio of two distinct gases (NO and ammonia) in temporal information that two selective sensors cannot capture, unlike gas chromatography, where ammonia is often absorbed by stainless steel [67]. This unique technology utilizes pure $\gamma$-phase tungsten trioxide's semiconducting, catalytic, and gas-sensing properties, as well as the redox reactions between the two biomarkers in the presence of the sensor [66].

\section{Available Therapeutics and Treatment Options}

Since the beginning of the COVID-19 pandemic, most countries and pharmaceutical companies worldwide have spent much time, effort, and expense developing effective vaccines and specific antiviral drugs against SARS$\mathrm{CoV}-2$. Concurrently, they tested a wide range of existing and approved drugs, particularly those that showed

Latest Insights for COVID-19 Diagnosis and Treatment promising results with other viral infections like SARS, MERS, Ebola, flu, and AIDS [68]. Four classes of drugs have now been described according to their mode of action as shown in Figure 2 including (i) viral entry and membrane fusion inhibitors, (ii) protease inhibitors, (iii) RdRp inhibitors, and (vi) immunomodulatory agents.

The S protein of SARS-CoV-2 anchors to the angiotensin-converting enzyme 2 (ACE2) receptor on the surface of epithelial cells [69]. The S protein is primed and activated by the host cell protease, transmembrane serine protease 2 (TMPRSS2), for virus entry [70]. Numerous candidate drugs including umifenovir, camostat mesylate, ACE inhibitors (ACEis), angiotensin receptor-1 blockers (ARBs), soluble recombinant human ACE2 (rhACE2), chloroquine phosphate, and hydroxychloroquine sulfate have been tested to disrupt virus attachment and fusion with cell membranes (Table 2A). Umifenovir, a broad-spectrum antiviral used as a prophylaxis against influenza, is currently approved in China and Russia but not FDA-licensed [63, 64]. Camostat mesylate has shown ability to inhibit SARS-CoV and MERS-CoV replication in cell culture and partial blockage of SARS-CoV-2 replication in Caco-2 and Vero-TMPRSS2 cells [71]. Several nonrandomized studies were conducted to confirm the safety and efficacy of both drugs in the treatment of COVID-19 [71-73]. However, the use of limited sample size and the contradictory results obtained discouraged their routine use in therapeutic purposes.

ACEis and ARBs are common drugs for the treatment of hypertension and heart failure [74]. During the SARS$\mathrm{CoV}$ outbreak, it was predicted that prolonged treatment with these drugs might protect from severe lung injury due to the elevation of ACE2 expression [75]. Conversely, several scientists claimed that frequent use of ACEis or ARBs could increase the likelihood of severe COVID-19 in patients with cardiovascular diseases since they upsurge the ability of SARS-CoV-2 to enter permissive cells. The latter prospect was disproved by two recent studies, which showed no evidence for increased severity or mortality of COVID-19 in 1,200 and 362 patients regularly treated with ACEis or ARBs [76]. rhACE2 is also proposed as a bait receptor that traps virus particles and prevent them from binding with cell-surface receptors [77]. It was recently announced by APEIRON Biologics AG that APN01, synonymous with rhACE2, was used to treat 200 COVID-19 patients in Austria, Germany, and Denmark [78].

Monoclonal antibodies (MAbs) are generated using human phage libraries, immunized animals, and memory $B$ cells from patients [72]. MAbs are more effective than 


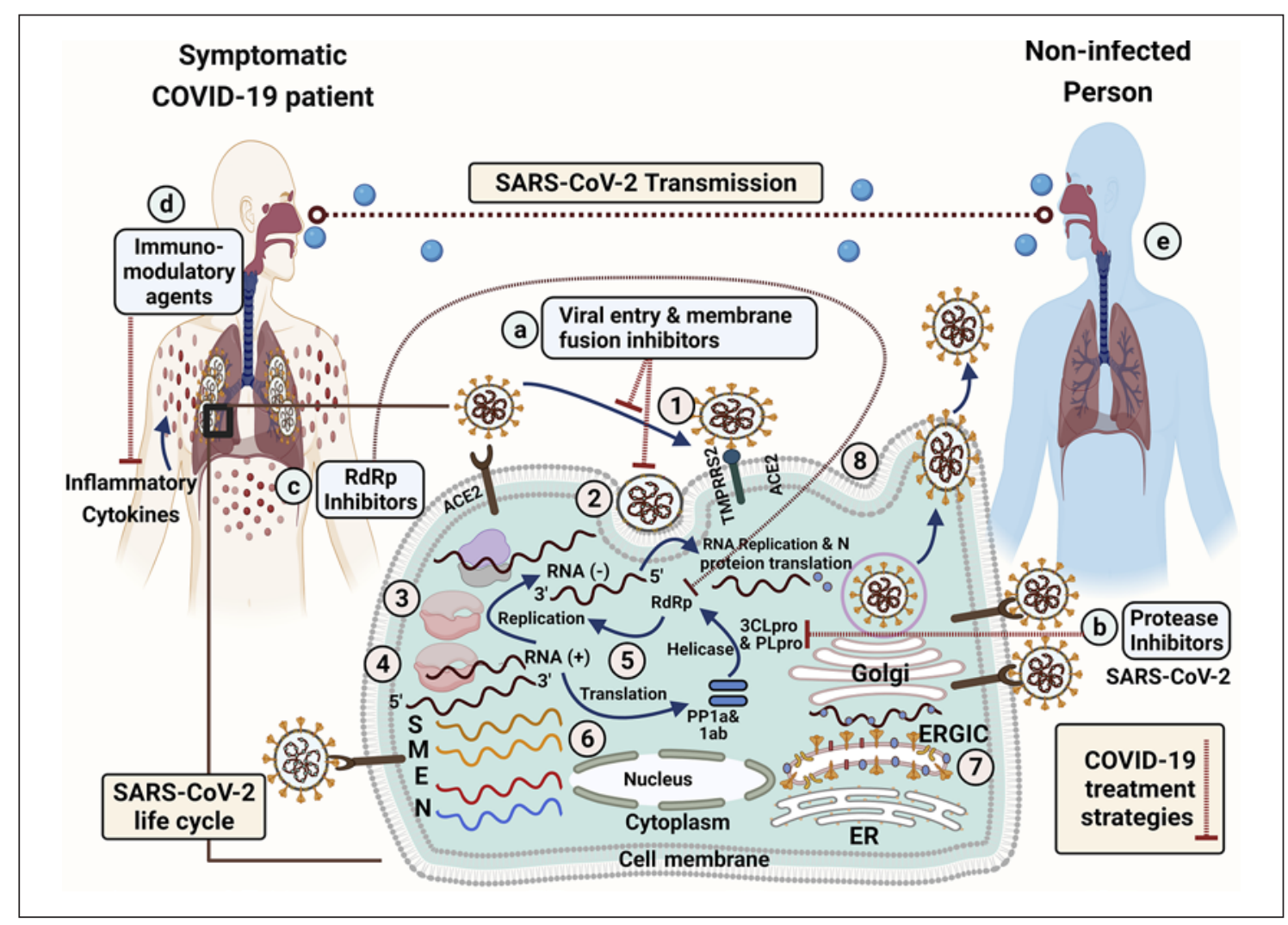

Fig. 2. Schematic representation of SARS-CoV-2 life cycle and the treatment strategies for COVID-19 pandemic. An infected person with COVID-19 can infect another person through their respiratory droplets, sneezing, and coughing. The SARS-CoV-2 life cycle includes (1) binding of SARS-CoV-2 spike protein with ACE2 receptor on the host cell's surface with the aid of the host protease enzyme TMPRSS2; (2) virus entry by fusion with the plasma membrane or by endocytosis mediated by endosome formation; (3) translation of the viral machinery of replication at cytoplasmic membranes; $(4,5)$ genomic and sub-genomic mRNA transcription through coordinated processes of continuous/discontinuous RNA synthesis determined by the viral replicase and mediated by viral proteases (e.g., 3CLpro and PLpro) and RdRP; (6) translation of structural and non-

using convalescent plasma in treatment of COVID-19 patients since they can be produced in greater quantities and possess reduced risk of antibody-dependent enhancement [73]. REGN-COV2 is a novel MAb cocktail that binds to the RBD of S1 or S2 subunits of SARS-CoV-2 spike protein to prevent virus entrance into a host cell. A double-blind, randomized controlled clinical trial using REGN-COV2 has shown reduction in the viral load, particularly in patients whose immune response did start to respond yet [74]. B38, H4, and CR3022 are three other MAbs that may be effective against SARS-CoV-2 in future trials $[75,79]$. structural proteins by viral-encoded enzymes and host cell machinery; (7) virions components are assembled at the ERGIC and obtain their membrane envelope; and (8) viruses are directed through the host secretory pathway and released by budding from the plasma membrane. The treatment options for COVID-19 include (a) viral entry and membrane fusion inhibitors (e.g., umifenovir, camostat mesylate, ACEi, ARBs, rhACE2, hydroxychloroquine); (b) protease inhibitors (e.g., LPV/r, darunavir/cobicistat, and disulfiram); (c) RdRp inhibitors (e.g., RDV, favipiravir, and ribavirin); and (d) immunomodulatory agents (e.g., tocilizumab and sarilumab, anakinra, nitazoxanide, thalidomide, and corticosteroid). Blue arrows for the subsequent step and a red "T" sign for inhibition. ERGIC, endoplasmic reticulum/Golgi intermediate compartment.

Chloroquine phosphate was promising in treating COVID-19 patients, compared to the control group, by improving lung imaging, advancing a negative infection transformation, and shortening the disease course [77]. The in vitro efficacy against SARS-CoV-2 was higher in hydroxychloroquine than chloroquine $\left(\mathrm{EC}_{50}: 0.72\right.$ vs. $5.47 \mu \mathrm{M})$ [77]. Complete virus clearance was reported in 6 patients concurrently treated with hydroxychloroquine and azithromycin within 5-6 days [79]. Nonetheless, a large-scale randomized clinical trial had recently shown that no notable difference in the hospital stay duration and the primary endpoint of mortality was observed 


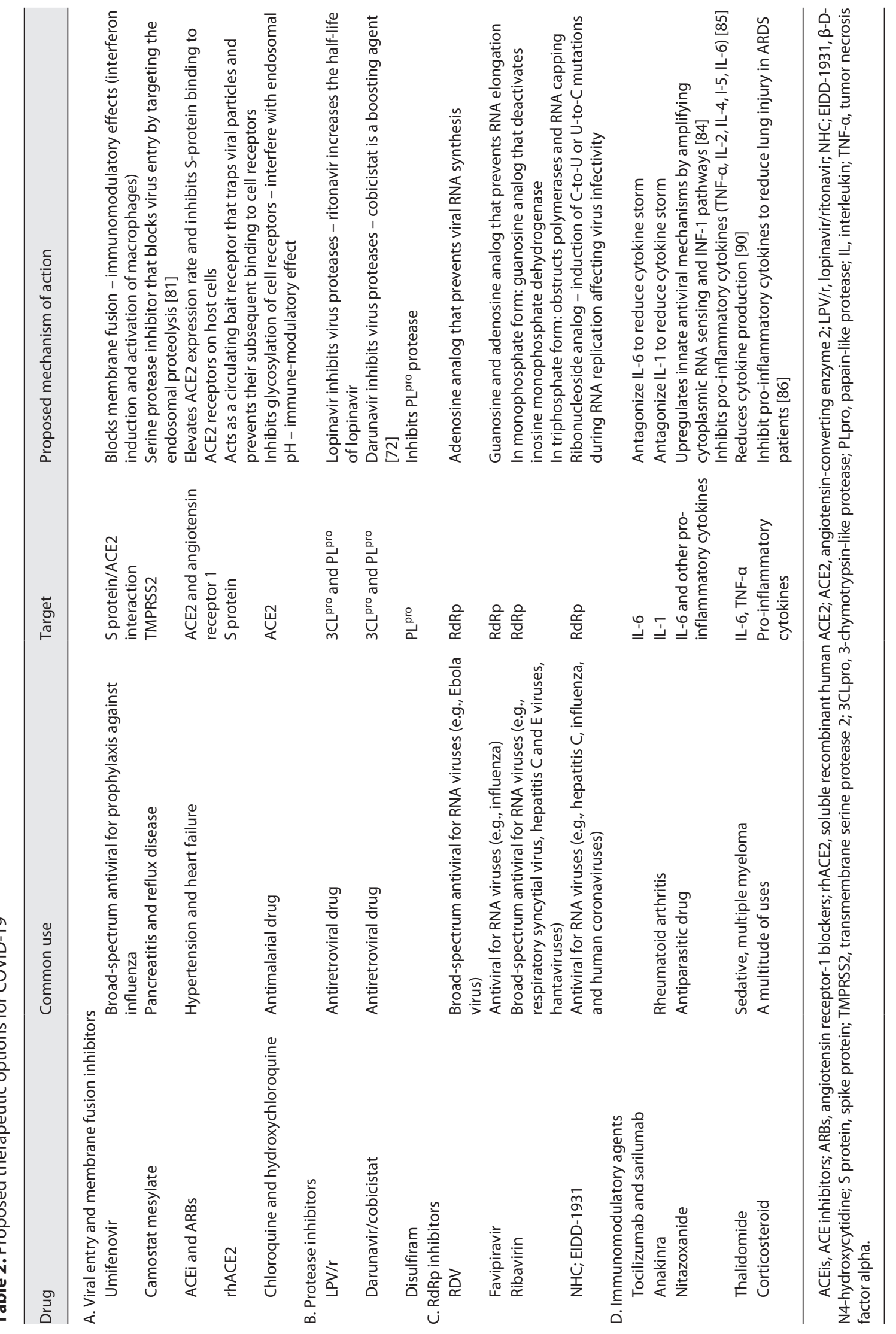


when hydroxychloroquine was used in 1,542 patients as compared to 3,132 patients with standard care only [80]. Therefore, the WHO has lately declared discontinuation of hydroxychloroquine from COVID-19 treatment regimens [81].

The protease inhibitor is another group of drugs that has long been used for treatment of AIDS (Table 2B). Lopinavir is typically formulated in combination with ritonavir (LPV/r) under the brand name Kaletra ${ }^{\circledR}$. The effect of LPV/r against human coronaviruses was previously confirmed in cell culture against SARS-CoV-1 and MERS-CoV [82] and recently against SARS-CoV-2 [83]. In a clinical trial, patients who received LPV/r $(n=99)$ showed significant clinical improvement and viral clearance after 14 days of treatment compared to patients who received standard care only $(n=100)$ [84]. Further studies have proven that the combination of LPV/r with interferon beta- $1 \mathrm{~b}$ and ribavirin are safe and superior to LPV/r alone in enhancing virus clearance, relieving symptoms, and facilitating discharge of patients with mild to moderate COVID-19 [85]. LPV/r is still an attractive candidate for the treatment of COVID-19 due to its commercial availability and large-scale producibility. Other protease inhibitors like darunavir (Prezista ${ }^{\circledR}$ ) and disulfiram (Antabuse ${ }^{\circledR}$ ) can inhibit replication of CoVs in vitro, and they did not show activity in clinically compatible concentrations [83]. Although the results of using protease inhibitor in the treatment of COVID-19 are discouraging till now, in silico studies of the protein-drug modeling showed a predictable strong interaction between HIV protease inhibitors and the active site of the SARS-CoV-2 protease. Hence, further studies on these compounds may provide a positive impact in the future [86].

Notably, RdRp inhibitors showed promising outcomes in COVID-19 patients (Table 2C) [87-89]. Remdesivir (RDV, GS-5734, Gilead), for example, blocked SARS-CoV-2 infection at low concentrations $\left(\mathrm{EC}_{50} 0.77\right.$ $\mu \mathrm{M})$ [88]. Animal studies in Rhesus macaques indicated that treatment with RDV is safe and effective compared to control animals [89]. The adverse effect of RDV on host cells is well-tolerated since human mitochondrial RdRp has a lower affinity to RDV than other adenosine analogs [90]. RDV was first utilized empirically with a 35-years-old COVID-19 patient in the USA and showed promising results [87]. Favipiravir (T-705, Avigan ${ }^{\circledR}$ ), another RdRp inhibitor, has shown effective action against SARS-CoV-2 in Vero E6 cells at high concentration ( $\mathrm{EC}_{50}$ $61.88 \mu \mathrm{M}$ ) [88], albeit some reports showed no effect even in concentrations up to $100 \mu \mathrm{M}$ [91]. A clinical study conducted on 80 patients in China has shown that favipiravir is more effective than $\mathrm{LPV} / \mathrm{r}$ with no profound adverse effect. Accordingly, favipiravir was approved in March 2020 for the treatment of COVID-19 in China [92]. Several clinical trials are now proceeding to evaluate the pharmacokinetics and antiviral activity of RDV and favipiravir either alone or in combination with other treatment options.

Other RdRp inhibitors, like $\beta$-D-N4-hydroxycytidine (EIDD-1931), were highly efficacious in preventing replication of SARS-CoV-1, SARS-CoV-2, and MERS-CoV in cell culture [93]. In contrary, ribavirin (Virazole ${ }^{\circledR}$ ) showed limited activity against SARS-CoV-2 in cell culture and required high concentration to inhibit viral replication. It was found that ribavirin is 100-times less effective than $\mathrm{RDV}\left(\mathrm{EC}_{50}\right.$ : $\left.109.5 \mu \mathrm{M}\right)$ [88]. The use of ribavirin in COVID-19 patients was evaluated either alone $(n=$ $111)$ or in combination with $\mathrm{LPV} / \mathrm{r}(n=41)$ in a clinical trial. The latter group showed no ARDS and mortalities. However, the use of high doses (1.2-2.4 g orally every 8 h) may exert a potential risk of toxicity in some patients [82].

Several collateral treatments are often used to decrease the severity and complications of COVID-19 and evade the inflammatory immune response developed in severe cases [94] (Table 2D). Drugs used to suppress the proinflammatory cytokines (e.g., interleukin [IL]-1, IL-2, IL6, IL-8, TNF- $\alpha$ ) such as MAbs (e.g., tocilizumab and sarilumab) and IL receptor inhibitors (e.g., anakinra) are widely emerged [60]. Anakinra (Kineret ${ }^{\circledR}$ ) is currently proceeding in clinical trials in China, Italy, Spain, and Greece to evaluate the safety and efficacy of using anakinra in COVID-19 patients with respiratory distress [94]. Nitazoxanide has demonstrated antiviral activity against SARS-CoV-2 in Vero E6 cells (EC50: $2.12 \mu \mathrm{M}$ at $48 \mathrm{~h}$ ) [88]. It had a vital immune-modulatory role by amplifying cytoplasmic RNA sensing and INF-1 pathways [95]. Nitazoxanide was also able to restrain pro-inflammatory cytokines in peripheral blood mononuclear cells and inhibit IL-6 production in mice [96]. It is essential to include nitazoxanide in controlled-randomized clinical trials to conclude its potential for improving the health condition of COVID-19 patients.

Corticosteroid helps reduce lung inflammation and cytokine storm and avoid acute lung injury and ARDS. Nevertheless, corticosteroid treatment is often associated with delayed virus clearance and an elevated secondary infection rate [97]. In the UK's national clinical trial RECOVERY, the corticosteroid dexamethasone was evaluated in COVID-19 patients, including severe cases, and was found to have benefits. According to the preliminary 
findings, the mortality rate for patients on ventilators was reduced by one-third, and for patients requiring only oxygen, the rate was cut by about one-fifth. The mortality rate was also decreased in another study conducted on 201 COVID-19 patients with ARDS after administering the corticosteroid drug methylprednisolone ( $46 \%$ vs. 61.8 in the control group) [98]. It was suggested that the reduction of severe illness and mortality rate are correlated to the early administration of low-dose methylprednisolone. The NIH, IDS, and other experts provided guidelines for using corticosteroids in COVID-19 patients based on the currently available information [99].

Cell therapies have demonstrated efficacy in treating conditions that were previously difficult to manage with conventional treatment modalities, including neurodegenerative, oncologic, and immunological disorders. Numerous cell therapy approaches have been studied such as induced pluripotent stem cells, mesenchymal stromal cells, and $T$ cells [100-103]. In a variety of indications, safety and efficacy results of cell therapy have suggested that cell therapy may be exploited to treat COVID-19 patients [100]. As of 1 January 2021, clinicaltrials.gov listed several cell therapy-based clinical trials targeting COVID-19 pathology. Mesenchymal stromal cells account for approximately $71 \%$ of the cells used in cell therapy clinical trials, with the remainder consisting of natural killer cells, $\mathrm{T}$ cells, and early apoptotic cells. Approximately $88 \%$ of the clinical trials are nowadays in phases 1 and 2, with only one trial in phase $2 / 3$ and one in phase $3[100,104]$.

\section{Conclusion and Perspectives}

COVID-19 is currently considered the most prominent health concern worldwide. Several options are available for sensitive and accurate diagnosis of COVID-19, among which rRT-PCR is the standard diagnostic tool in almost all countries. The rapid spread of SARS-CoV-2 and its burden on health and the economy has encouraged research and industrial foundations to pursuit effective therapeutic solutions for the disease. A group of medications has been developed or repurposed to help virus clearance, symptoms relief, and rapid discharge of patients from healthcare facilities. These drug candidates can inhibit virus entry, membrane fusion, viral RNA synthesis, or protease activity. Immunomodulatory agents and corticosteroids are proposed to be used in severe cases to suppress the cytokine storm induced by pro-inflammatory cytokines. Nevertheless, the safety and efficacy of these drugs require further evaluation in controlled randomized clinical trials.

\section{Acknowledgments}

All the figures were created with BioRender.com.

\section{Conflict of Interest Statement}

The authors have no conflicts of interest to declare.

\section{Funding Sources}

The materials included in the review are all property of the authors.

\section{Author Contributions}

Conceptualization (S.S.H., M.R.S., N.M.T., and H.M.A.), literature search and data analysis (S.S.H., M.R.S., and N.M.T.), original draft preparation (S.S.H., M.R.S., N.M.T., S.A.R., M.A., A.F., and H.M.), design of figures (S.S.H.), review and editing (H.M.A.), and supervision (H.M.A.). All the authors approved the final manuscript.

\section{References}

1 Lu R, Zhao X, Li J, Niu P, Yang B, Wu H, et al. Genomic characterisation and epidemiology of 2019 novel coronavirus: implications for virus origins and receptor binding. Lancet. 2020;395(10224):565-74.

2 Riou J, Althaus CL. Pattern of early humanto-human transmission of Wuhan 2019 novel coronavirus (2019-nCoV), December 2019 to January 2020. Eurosurveillance. 2020;25:2000058.
3 Li Q, Guan X, Wu P, Wang X, Zhou L, Tong $\mathrm{Y}$, et al. Early transmission dynamics in Wuhan, China, of novel coronavirus: infected pneumonia. N Engl J Med. 2020; 382(13):1199-207.

4 Xie HT, Jiang SY, Xu KK, Liu X, Xu B, Wang L, et al. SARS-CoV-2 in the ocular surface of COVID-19 patients. Eye Vis. 2020;7(1):23.
5 Cascella M, Rajnik M, Cuomo A, Dulebohn SC, Di Napoli R. Features, evaluation and treatment coronavirus (COVID-19) [Internet]. StatPearls: StatPearls Publishing; 2020.

6 Li X, Geng M, Peng Y, Meng L, Lu S. Molecular immune pathogenesis and diagnosis of COVID-19. J Pharm Anal. 2020;10: 102-8.

7 Pan Y, Zhang D, Yang P, Poon LLM, Wang Q. Viral load of SARS-CoV-2 in clinical samples. Lancet Infect Dis. 2020;20:411-2. 
8 Song F, Zhang X, Zha Y, Liu W. COVID-19: recommended sampling sites at different stages of the disease. J Med Virol. 2020; 92(9):1383-5.

9 De Wit E, Van Doremalen N, Falzarano D, Munster VJ. SARS and MERS: Recent insights into emerging coronaviruses. Nat Rev Microbiol. 2016;14:523-34.

10 Huang C, Wang Y, Li X, Ren L, Zhao J, Hu $\mathrm{Y}$, et al. Clinical features of patients infected with 2019 novel coronavirus in Wuhan, China. Lancet. 2020;395(10223):497-506.

11 Groneberg DA, Hilgenfeld R, Zabel P. Molecular mechanisms of severe acute respiratory syndrome (SARS) [Internet]. Resp Res BioMed Central. 2005;6:1-16.

12 Su S, Wong G, Shi W, Liu J, Lai ACK, Zhou J, et al. Epidemiology, genetic recombination, and pathogenesis of coronaviruses. Trends Microbiol. 2016;24:490-502.

13 Chen Y, Liu Q, Guo D. Emerging coronaviruses: genome structure, replication, and pathogenesis [Internet]. J Med Virol. 2020; 92:418-23.

14 Wu A, Peng Y, Huang B, Ding X, Wang X, Niu $\mathrm{P}$, et al. Genome composition and divergence of the novel coronavirus (2019$\mathrm{nCoV}$ ) originating in China. Cell Host Microbe. 2020;27(3):325-8.

15 Strauss JH, Strauss EG. The alphaviruses: gene expression, replication, and evolution. Microbiol Rev. 1994;58:491-562.

16 Hukowska-Szematowicz B. Genetic variability and phylogenetic analysis of Lagovirus europaeus strains GI.1 (RHDV) and GI.2 (RHDV2) based on the RNA-dependent RNA polymerase (RdRp) coding gene. Acta Biochim Pol. 2020;67(1):111-22.

17 McIntosh K, Peiris JSM. Coronaviruses. Clinical virology. $3 \mathrm{rd}$ ed. American Society of Microbiology; 2009. p. 1155-71.

18 WHO MERS-CoV Global Summary and risk assessment: 5 December 2016. 2017.

19 Widjaja I, Wang C, van Haperen R, Gutiérrez-Álvarez J, van Dieren B, Okba NMA, et al. Towards a solution to MERS: protective human monoclonal antibodies targeting different domains and functions of the MERS-coronavirus spike glycoprotein. Emerg Microbes Infect. 2019;8(1):516-30.

20 Masters PS. The molecular biology of coronaviruses. Adv Virus Res. 2006;65:193292.

21 de Haan CA, Kuo L, Masters PS, Vennema $\mathrm{H}$, Rottier PJ. Coronavirus particle assembly: primary structure requirements of the membrane protein. J Virol. 1998;72(8): 6838-50.

22 Schoeman D, Fielding BC. Coronavirus envelope protein: current knowledge. Virol J. 2019;16:1-22.

23 de Haan CA, Rottier PJ. Molecular interactions in the assembly of coronaviruses. Adv Virus Res. 2005;64:165-230.

24 McBride R, van Zyl M, Fielding BC. The coronavirus nucleocapsid is a multifunctional protein. Viruses. 2014;6:2991-3018.
25 Boscarino JA, Logan HL, Lacny JJ, Gallagher TM. Envelope protein palmitoylations are crucial for murine coronavirus assembly. J Virol. 2008;82(6):2989-99.

26 Fehr AR, Perlman S. Coronaviruses: an overview of their replication and pathogenesis. Coronaviruses: methods and protocols. New York: Springer; 2015. p. 1-23.

27 Carter LJ, Garner LV, Smoot JW, Li Y, Zhou Q, Saveson CJ, et al. Assay techniques and test development for COVID-19 diagnosis. ACS Cent Sci. 2020;6(5):591-605.

28 Shen M, Zhou Y, Ye J, Abdullah AL-maskri AA, Kang Y, Zeng S, et al. Recent advances and perspectives of nucleic acid detection for coronavirus. J Pharma Anal. 2020;10: 97-101.

29 Tang YW, Schmitz JE, Persing DH, Stratton CW. Laboratory diagnosis of COVID-19: current issues and challenges. J Clin Microbiol. 2020:58.

30 Corman VM, Landt O, Kaiser M, Molenkamp R, Meijer A, Chu DKW, et al. Detection of 2019 novel coronavirus (2019$\mathrm{nCoV})$ by real-time RT-PCR. Eurosurveillance. 2020;25(3):2000045.

31 Zhou P, Lou YX, Wang XG, Hu B, Zhang L, Zhang W, et al. A pneumonia outbreak associated with a new coronavirus of probable bat origin. Nature. 2020;579(7798): 270-3.

32 Udugama B, Kadhiresan P, Kozlowski HN, Malekjahani A, Osborne M, Li VYC, et al. Diagnosing COVID-19: the disease and tools for detection. ACS Nano. 2020;14: 3822-35.

33 Chan JFW, Yip CCY, To KKW, Tang THC, Wong SCY, Leung KH, et al. Improved molecular diagnosis of COVID-19 by the novel, highly sensitive and specific COVID19-RdRp/Hel real-time reverse transcription-PCR assay validated in vitro and with clinical specimens. J Clin Microbiol. 2020;58:e00310-20 .

34 CDC Diagnostic Tests for COVID-19 CDC [Internet].

35 Lamb LE, Bartolone SN, Ward E, Chancellor MB. Rapid detection of novel coronavirus (COVID-19) by reverse transcriptionloop-mediated isothermal amplification. PLoS One. 2020 Jun 12;15(6):e0234682.

36 Harahwa TA, Lai Yau TH, Lim-Cooke MS, Al-Haddi S, Zeinah M, Harky A. The optimal diagnostic methods for COVID-19. Diagnosis. 2020;7(4):349-56.

37 Huang WE, Lim B, Hsu CC, Xiong D, Wu $\mathrm{W}, \mathrm{Yu} \mathrm{Y}$, et al. RT-LAMP for rapid diagnosis of coronavirus SARS-CoV-2. Microb Biotechnol. 2020;13(4):950-61.

38 Zhang Y, Odiwuor N, Xiong J, Sun L, Nyaruaba $\mathrm{RO}$, Wei $\mathrm{H}$, et al. Rapid molecular detection of SARS-CoV-2 (COVID-19) virus RNA using colorimetric LAMP. Med Rxiv. 2020
39 Lu R, Wu X, Wan Z, Li Y, Zuo L, Qin J, et al. Development of a novel reverse transcription loop-mediated isothermal amplification method for rapid detection of SARS-CoV-2 [Internet]. Virol Sinica. 2020; 35:344-7.

40 Yan C, Cui J, Huang L, Du B, Chen L, Xue G, et al. Rapid and visual detection of 2019 novel coronavirus (SARS-CoV-2) by a reverse transcription loop-mediated isothermal amplification assay. Clin Microbiol Infect. 2020;26(6):773-9.

41 González-González E, Lara-Mayorga IM, Rodríguez-Sánchez IP, LeónDe FY, GarcíaRubio A, Garciaméndez-Mijares CE, et al. Scaling diagnostics in times of COVID-19: colorimetric loop-mediated isothermal amplification (LAMP) assisted by a 3Dprinted incubator for cost-effective and scalable detection of SARS-CoV-2. MedRxiv. 2020

42 Kumar R, Nagpal S, Kaushik S, Mendiratta S. COVID-19 diagnostic approaches: different roads to the same destination [Internet]. Virus Dis. 2020;31:97-105.

43 Hou T, Zeng W, Yang M, Chen W, Ren L, Ai J, et al. Development and evaluation of a CRISPR-based diagnostic for 2019-novel coronavirus [Internet]. medRxiv. 2020.

44 Massart S, Chiumenti M, De Jonghe K, Glover R, Haegeman A, Koloniuk I, et al. Virus detection by high-throughput sequencing of small RNAs: large-scale performance testing of sequence analysis strategies. Phytopathology. 2019;109(3):488-97.

45 Dara M, Talebzadeh M. CRISPR/Cas as a potential diagnosis technique for $\mathrm{CO}$ VID-19. Avicenna J Med Biotechnol. 2020; 12:201-2.

46 Joung J, Ladha A, Saito M, Segel M, Bruneau R, Huang MLW, et al. Point-of-care testing for COVID-19 using SHERLOCK diagnostics [Internet]. MedRxiv. 2020.

47 O'Connell MR. Molecular mechanisms of RNA targeting by Cas13-containing Type VI CRISPR - Cas systems [Internet]. J Mol 9;431:66-87.

48 Gootenberg JS, Abudayyeh OO, Lee JW, Essletzbichler P, Dy AJ, Joung J, et al. Nucleic acid detection with CRISPR-Cas13a/ C2c2. Science. 2017;356(6336):438-42.

49 Cheng MP, Papenburg J, Desjardins M, Kanjilal S, Quach C, Libman M, et al. Diagnostic testing for severe acute respiratory syndrome-related coronavirus 2: a narrative review. Ann Inter Med. 2020;172:72634.

$50 \mathrm{Lu} \mathrm{X}$, Chen Y, Bai B, Hu H, Tao L, Yang J, et al. Immune responses against severe acute respiratory syndrome coronavirus induced by virus-like particles in mice. Immunology. 2007;122(4):496-502.

51 Guo L, Ren L, Yang S, Xiao M, Chang D, Yang F, et al. Profiling early humoral response to diagnose novel coronavirus disease (COVID-19). Clin Infect Dis. 2020; 71(15):778-85. 
52 Abduljalil JM. Laboratory diagnosis of SARS-CoV-2: available approaches and limitations [Internet]. New microbes and new infections: Elsevier Ltd; 2020.

53 Guan W, Ni Z, Hu Y, Liang W, Ou C, He J, et al. Clinical characteristics of coronavirus disease 2019 in China. N Engl J Med. 2020; 382(18):1708-20.

54 Shi H, Han X, Jiang N, Cao Y, Alwalid O, $\mathrm{Gu}$ J, et al. Radiological findings from 81 patients with COVID-19 pneumonia in Wuhan, China: a descriptive study. Lancet Infect Dis. 2020;20(4):425-34.

55 The Importance of Chest CT Scan in COVID-19| Tenda | Acta Medica Indonesiana [Internet].

56 Zhangjin J, Dong X, Caoyuan Y, Yuandong Y, Yang Y, Qin Y, et al. Clinical characteristics of 140 patients infected with SARSCoV-2 in Wuhan, China. Allergy Eur J Allergy Clin Immunol. 2020;75(7):1730-41.

57 Zhou F, Yu T, Du R, Fan G, Liu Y, Liu Z, et al. Clinical course and risk factors for mortality of adult inpatients with COVID-19 in Wuhan, China: a retrospective cohort study. Lancet. 2020;395(10229):1054-62.

58 Fang Y, Zhang H, Xie J, Lin M, Ying L, Pang $\mathrm{P}$, et al. Sensitivity of chest CT for COVID-19: comparison to RT-PCR. Radiology. 2020;296:E115-7.

59 Rubin GD, Ryerson CJ, Haramati LB, Sverzellati N, Kanne JP, Raoof S, et al. The role of chest imaging in patient management during the covid-19 pandemic: a multinational consensus statement from the fleischner society. Radiology. 2020;296(1):17280.

60 Bernheim A, Mei X, Huang M, Yang Y, Fayad ZA, Zhang N, et al. Chest CT findings in coronavirus disease 2019 (COVID-19): relationship to duration of infection [Internet]. Radiology. 2020;295:68591.

61 Xiong Y, Sun D, Liu Y, Fan Y, Zhao L, Li X, et al. Clinical and high-resolution CT features of the COVID-19 infection: comparison of the initial and follow-up changes. Invest Radiol. 2020;55(6):332-9.

62 Gouma PI, Prasad AK, Iyer KK. Selective nanoprobes for "signalling gases". Nanotechnology. 2006;17(4):S48.

63 Gouma P. Nanoscale polymorphic oxides for selective chemosensors. Sci Adv Mat. 2011;3(5):787-93.

64 Wang L, Kalyanasundaram K, Stanacevic M, Gouma P. Nanosensor device for breath acetone detection. Sen Lett. 2010;8(5):70912.

$65 \mathrm{Hu}$ W, Wan L, Jian Y, Ren C, Jin K, Su X, et al. Electronic noses: from advanced materials to sensors aided with data processing. Adv Mater Technol. 2019;4(2): 1800488.

66 Exline MC, Stanacevic M, Bowman AS, Gouma PI. Exhaled nitric oxide detection for diagnosis of COVID-19 in critically ill patients. PLoS One. 2021;16(10):e0257644.
67 Zaffaroni R, Ripepi D, Middelkoop J, Mulder FM. Gas chromatographic method for in situ ammonia quantification at parts per billion levels. ACS Energy Lett. 2020;5(12):3773-7.

68 Mulangu S, Dodd LE, Davey RT, Tshiani Mbaya O, Proschan M, Mukadi D, et al. A randomized, controlled trial of ebola virus disease therapeutics. N Engl J Med. 2019; 381(24):2293-303.

69 Ou X, Liu Y, Lei X, Li P, Mi D, Ren L, et al. Characterization of spike glycoprotein of SARS-CoV-2 on virus entry and its immune cross-reactivity with SARS-CoV. Nat Commun. 2020;11(1):1620.

70 Martinez MA. Compounds with therapeutic potential against novel respiratory 2019 coronavirus. Antimicrob Agents Chemother. 2020;64(5).

71 Hoffmann M, Kleine-Weber H, Schroeder S, Krüger N, Herrler T, Erichsen S, et al. SARS-CoV-2 cell entry depends on ACE2 and TMPRSS2 and is blocked by a clinically proven protease inhibitor. Cell. 2020; 181(2):271-80.e8.

72 Mo Y, Fisher D. A review of treatment modalities for Middle East respiratory syndrome. J Antimicrob Chemother. 2016; 71(12):3340-50.

73 Brouwer PJM, Caniels TG, van der Straten $\mathrm{K}$, Snitselaar JL, Aldon Y, Bangaru S, et al. Potent neutralizing antibodies from COVID-19 patients define multiple targets of vulnerability. Science. 2020;369(6504): 643-50.

74 Weinreich DM, Sivapalasingam S, Norton T, Ali S, Gao H, Bhore R, et al. REGNCOV2, a neutralizing antibody cocktail, in outpatients with Covid-19. N Engl J Med. 2021;384(3):238-51.

75 Tian X, Li C, Huang A, Xia S, Lu S, Shi Z, et al. Potent binding of 2019 novel coronavirus spike protein by a SARS coronavirusspecific human monoclonal antibody. Emerg Microbes Infect. 2020;9(1):382-5.

76 Wu Y, Wang F, Shen C, Peng W, Li D, Zhao $\mathrm{C}$, et al. A noncompeting pair of human neutralizing antibodies block COVID-19 virus binding to its receptor ACE2. Science. 2020;368(6496):1274-8.

77 Gao J, Tian Z, Breakthrough YX. Chloroquine phosphate has shown apparent efficacy in treatment of COVID-19 associated pneumonia in clinical studies [Internet]. BioSci Trends. 2020;14:72.

78 Yao X, Ye F, Zhang M, Cui C, Huang B, Niu $\mathrm{P}$, et al. In vitro antiviral activity and projection of optimized dosing design of hydroxychloroquine for the treatment of severe acute respiratory syndrome coronavirus 2 (SARS-CoV-2). Clin Infect Dis. 2020; 71(15):732-9.

79 Gautret P, Lagier JC, Parola P, Hoang VT, Meddeb L, Mailhe M, et al. Hydroxychloroquine and azithromycin as a treatment of COVID-19: results of an open-label nonrandomized clinical trial. Int J Antimicrob Agents. 2020;56(1):105949.
80 News - RECOVERY Trial [Internet].

81 WHO discontinues hydroxychloroquine and lopinavir/ritonavir treatment arms for COVID-19 [Internet].

82 Chu CM, Cheng VCC, Hung IFN, Wong MML, Chan KH, Chan KS, et al. Role of lopinavir/ritonavir in the treatment of SARS: initial virological and clinical findings. Thorax. 2004;59(3):252-6.

83 Yamamoto N, Matsuyama S, Hoshino T, Yamamoto N. Nelfinavir inhibits replication of severe acute respiratory syndrome coronavirus 2 in vitro. bioRxiv. 2020.

84 Cao B, Wang Y, Wen D, Liu W, Wang J, Fan $\mathrm{G}$, et al. A trial of lopinavir ritonavir in adults hospitalized with severe Covid-19. N Engl J Med. 2020;382(19):1787-99.

85 Hung IFN, Lung KC, Tso EYK, Liu R, Chung TWH, Chu MY, et al. Triple combination of interferon beta-1b, lopinavirritonavir, and ribavirin in the treatment of patients admitted to hospital with COVID-19: an open-label, randomised, phase 2 trial. Lancet. 2020;395(10238): 1695-704.

86 Kumar S, Zhi K, Mukherji A, Gerth K. Repurposing antiviral protease inhibitors using extracellular vesicles for potential therapy of COVID-19. Viruses. 2020;12:486.

87 Holshue ML, DeBolt C, Lindquist S, Lofy $\mathrm{KH}$, Wiesman J, Bruce H, et al. First case of 2019 novel coronavirus in the United States. N Engl J Med. 2020;382(10):929-36.

88 Wang M, Cao R, Zhang L, Yang X, Liu J, Xu $\mathrm{M}$, et al. Remdesivir and chloroquine effectively inhibit the recently emerged novel coronavirus $(2019-\mathrm{nCoV})$ in vitro [Internet]. Cell Res. 2020;30:269-71.

89 Williamson BN, Feldmann F, Schwarz B, Meade-White K, Porter DP, Schulz J, et al. Clinical benefit of remdesivir in rhesus macaques infected with SARS-CoV-2. Nature. 2020;585:273-6.

90 Tchesnokov EP, Feng JY, Porter DP, Götte $M$. Mechanism of inhibition of ebola virus RNA-dependent RNA polymerase by remdesivir. Viruses. 2019;11(4):326.

91 Choy KT, Wong AYL, Kaewpreedee P, Sia SF, Chen D, Hui KPY, et al. Remdesivir lopinavir, emetine, and homoharringtonine inhibit SARS-CoV-2 replication in vitro. Antiviral Res. 2020:178.

92 Jean SS, Lee PI, Hsueh PR. Treatment options for COVID-19: the reality and challenges [Internet]. J Microbiol Immunol Infect. 2020;53:436-43.

93 Sheahan TP, Sims AC, Zhou S, Graham RL, Pruijssers AJ, Agostini ML, et al. An orally bioavailable broad-spectrum antiviral inhibits SARS-CoV-2 in human airway epithelial cell cultures and multiple coronaviruses in mice. Sci Transl Med. 2020. 12(541):eabb5883

94 Felsenstein S, Herbert JA, McNamara PS, Hedrich CM. COVID-19: immunology and treatment options [Internet]. Clin Immunol. 2020;215:108448. 
95 Jasenosky LD, Cadena C, Mire CE, Borisevich V, Haridas V, Ranjbar S, et al. The FDA-approved oral drug nitazoxanide amplifies host antiviral responses and inhibits Ebola virus. iScience. 2019;19:1279-90.

96 Rossignol JF. Nitazoxanide, a new drug candidate for the treatment of Middle East respiratory syndrome coronavirus. J Infect Public Health. 2016;9(3):227-30.

97 Sanders JM, Monogue ML, Jodlowski TZ, Cutrell JB. Pharmacologic treatments for coronavirus disease 2019 (COVID-19): a review [Internet]. J Am Med Assoc. 2020; 323:1824-36

98 Wu C, Chen X, Cai Y, Xia J, Zhou X, Xu S, et al. Risk factors associated with acute respiratory distress syndrome and death in patients with coronavirus disease 2019 pneumonia in Wuhan, China. JAMA Intern Med. 2020;180(7):934.
99 Bhimraj A, Morgan RL, Shumaker AH, Lavergne V, Baden L, Cheng VCC, et al. Infectious diseases society of America guidelines on the treatment and management of patients with COVID-19. Clin Infect Dis. 2020

100 Zaki MM, Lesha E, Said K, Kiaee K, Robinson-McCarthy L, George H, et al. Cell therapy strategies for COVID-19: current approaches and potential applications. Sci Adv. 2021;7(33):5995-6006.

101 Feins S, Kong W, Williams EF, Milone MC, Fraietta JA. An introduction to chimeric antigen receptor (CAR) T-cell immunotherapy for human cancer. Am J Hematol. 2019;94(S1):S3-9.
102 Singh VK, Kalsan M, Kumar N, Saini A, Chandra R. Induced pluripotent stem cells: applications in regenerative medicine, disease modeling, and drug discovery. Front Cell Dev Biol. 2015;3:2.

103 Parekkadan B, Milwid JM. Mesenchymal stem cells as therapeutics. Annu Rev Biomed Eng. 2010;12:87-117.

104 Lanzoni G, Linetsky E, Correa D, Messinger Cayetano S, Alvarez RA, Kouroupis $D$, et al. Umbilical cord mesenchymal stem cells for COVID-19 acute respiratory distress syndrome: a double-blind, phase $1 / 2 \mathrm{a}$, randomized controlled trial. Stem Cells Transl Med. 2021;10(5):66073. 